\title{
An Evaluation of the Effectiveness of Tax Incentives on Economic Growth: Evidence from Nigeria
}

\author{
Chukwuma C. Ugwu (Ph.D) ${ }^{1^{*}} \quad$ Ifeanyi C. Nnado (Ph.D) ${ }^{2} \quad$ Sonia Idemudia $^{1}$ \\ 1.Department of Accounting, Federal University, Wukari, Nigeria \\ 2.Department of Accounting, Enugu State University of Science and Technology, Enugu, Nigeria
}

\begin{abstract}
Assessing the Relationship between Tax Incentives and Economic Growth in Nigeria is aimed at determining the effect of tax incentives on economic growth in Nigeria. The study adopted Ex Post Facto Research Design and time-series data was used. Relevant secondary data for this study were collected from the Central Bank of Nigeria (CBN) Statistical Bulletin and the National Bureau of Statistics (NBS) and the Federal Inland Revenue Service (FIRS). The study employed ordinary least square estimation and used regression analysis to test the relationship between Tax Incentives and Economic Growth in Nigeria. The study shows that tax incentive policy is positively and significantly related to gross domestic product. The findings showed that there is a degree of relationship between corporate income tax and gross domestic product; and that there is degree of co-variability between investment allowance and gross domestic product in Nigeria. The implication of this finding is that since tax incentives have positive and significant impact on gross domestic product, policy reform in other factors that affect economic growth is needed also to complement these incentives so that a better result can be achieved. The study recommends that tax incentive policy should be designed bearing in mind the economy's macroeconomic objectives like rapid economic growth and development.
\end{abstract}

Keywords: Tax incentives, Economic growth, Corporate Income Tax, Investment Allowance

DOI: $10.7176 /$ RJFA/11-14-13

Publication date:July $31^{\text {st }} 2020$

\section{Introduction:}

\subsection{Background to the study}

The National Economic Empowerment and Development Strategy (NEEDS 2004), in its report revealed that the Nigerian economy before the Independence in 1960 was agricultural based. Then agricultural sector was employing the largest percentage of the workforce and contributing the greatest share of the national GDP. But from the late 1970s, oil became prominent and government shifted from Agricultural sector to oil sub-sector. Then the economy was open to the international communities and so much importation killed domestic manufacturing. With stiff competition from foreign firms, many domestic companies that could not compete with foreign companies closed down. In the early 1980s, oil prices collapsed in the international market, as a result, government revenue fell and domestic production of goods and services fall as well, government could not finance the importation of goods and services and as a result, unemployment and price of goods and services rose creating both internal and external imbalance.

As a result of all these, in the mid-1980s precisely in 1986, a Structural Adjustment Programme (SAP) was introduced despite an overwhelmingly negative response from the Nigerian public in the 1985 referendum. Critics of SAP accused the IMF-supported SAP for the economic re-colonisation of Nigeria; (Ohiorhenuan 1987), Onimode (1989) argued that SAP was generating growth without development, creating benefits for the 'rich and strong' while imposing 'the burden of adjustment on the weak and poor who are least able to bear it'. Then the Nigerian economy was faring poorly, still reeling from the deterioration of balance of payments and poor terms of trade precipitated by the oil glut of the late 1970s and early 1980s. SAP's objectives comprised: restructuring and diversification of the Nigerian productive base to promote non-oil sectors and reduce dependency on oil revenues and imports; restoration of medium-term balance of payments and fiscal equilibrium; promotion of noninflationary economic growth; and reducing unproductive investments in the public sector while intensifying the growth potential of the private sector.

Many economic measures were undertaken to bring the economy back to a sustainable economic track. One of such economic measures is the tax reforms. The essence of tax incentives is to reduce the cost of production and stimulate output growth leading to the demand for domestic resources - (labour and raw materials). Government fiscal policies frequently focus on stimulating a healthy business environment with the assumption that it will lead to a long-term economic growth (Prillaman and Meier 2014). The general idea is that government tax rates are negatively correlated with economic growth and as a result, government attempts to reduce tax rates so as to stimulate economic growth.

In order to overcome the low output of goods and services, rising price of goods and high unemployment, government introduced some tax reform measures in other to stimulate the growth of the economy and put it back 
to the path of the sustainable economic growth and development. Within the past years, the government has progressively introduced a number of tax incentives designed to promote investment, employment, product mix and various other aspects of industry.

The practice of governments offering tax incentives to firms considering locating operations in their jurisdictions, as well as to existing firms that are expanding operations, has become a common practice with no abatement of this practice apparent in the near future (Hoyt, Jepsen and Troske 2008). They argue that these incentive programs are used in the hopes of attracting very visible investment projects, high-technology firms, also to encourage existing firms to add new capacity and create jobs. Firms may be awarded a certain amount of incentives but they are only able to claim the incentives once they meet certain criteria, such as creating a certain number of jobs. Foreign capital can be attracted depending on the extent of tax incentives granted to foreign investors.

Empirical studies like those of (Morisset 2003, Alan and Peter 2004 and Hoyt, Jepsen and Troske 2008) have reported different views on tax incentives as a catalyst for economic growth and development. One school of thought (Holland and Van 1996) believes that tax incentives encourage economic growth and development. They maintain that many developing and transitional countries in the world offer incentives for investment. This certainly relates to real investment in productive activities and are often directed to foreign investors on the ground that there is insufficient domestic capital that will bring the desired level of economic development and that international investment will always bring with it modern technology and management techniques, while (Kwewuni 1996) believes that it reduces revenue to the government. Kwewumi on the other hand, argued that tax incentives by their nature represent revenue costs to the government and may be drains on the revenue of the government if not well focused. This is because government would have deprived itself of the revenue that would have been generated from tax.

The Government of Nigeria has put in place a number of investment incentives for the stimulation of private sector investment from within and outside the country. While some of these incentives cover all sectors, others are limited to some specific sectors. However, it is not very clear how tax incentives actually affect the growth of the economy, because, with all these measures and policies so far taken, Nigerian economy has not shown any appreciable progress going by the review of the Gross Domestic Product (GDP) growth rate from 1986 - 2018. Years after the economic reforms, investment in industries is reducing, unemployment is increasing and domestic output has continued to stagnate. The question now is what are the effects of these incentives on the Nigerian economic growth if those problems have continued to linger? Nigeria still remains one of the developing nations. Given this gap, the study seeks to examine the economic impact of tax incentives on the Nigerian economic growth.

\subsection{Objective}

The Nigerian economy is not really doing very well, some companies are closing down and not very many are coming up. Apostles of tax incentives hold the view that tax incentives encourage economic growth and development while another school of thought believes that tax incentives reduce revenue to the government. They argued that tax incentives by their nature represent revenue loss to the government and may be drains on the revenue of the government if not well focused. Objective of this study is to assess the economic impact of tax incentives on economic growth in Nigeria.

Here the multiple regressions were used to analyze the impact of tax incentives on the economic growth in Nigeria. This study used yearly data generated from Central Bank of Nigeria statistical bulletin, the Annual Abstract of the National Bureau of Statistics and the Federal Inland Revenue Service (FIRS) between 1981 and 2016.

\section{Conceptual Framework:}

\subsection{Concept of Tax Incentive}

Tax incentives are designed to encourage economic growth and development which by extension should increase the gross domestic product of the nation. They are designed to encourage investments in certain preferred sectors of the economy, sometimes; they are geared towards attracting inflow of foreign exchange to complement domestic supplies for rapid economic growth and development. Tax incentive can be defined as a deduction, exclusion or exemption from tax liability that is offered as an enticement to investors so as to encourage investment in certain preferred sectors of the economy for a certain period. According to Bassey (2013), tax incentives are those special exclusion exemptions or deduction from income or tax liability offered to tax payers by the government as an encouragement to engage in specified activities. Fletcher (2002) in his view has defined tax incentive as any tax provision which to a qualified investment project represents a favorable deviation from the normal provisions applicable to all investment projects. For example, when the corporate income tax rate that is allowed for foreign investment is set at half or below the rate that applies to all domestic industries, then the tax provision will constitute a tax incentive. But if on the other hand the provision is simply to set a low corporate income tax rate to all companies, then the provision would no longer constitute a tax incentive (Fletcher 2002). These incentives 
include: reduced company income tax rates (company income tax allowance), tax holidays (i.e. no payment of taxes for a period of time), accelerated depreciation (i.e. fast write-off of businesses depreciation on their assets), investment tax credits and allowance (i.e. reducing business taxes based on the level of investment; this is difference from the normal initial and annual allowances or the normal depreciation) and indirect taxes exemptions; for instance, import tariffs.

\subsection{Concept of Economic Growth:}

Economic growth is defined as an increase in the production output of an economy over a defined period of time. Economic growth according to Dwivedi (2004) is a sustained increase in the net national product or the per capita national output over a long period of time. Traditionally, aggregate economic growth is measured in terms of gross national Product (GNP) or gross domestic product (GDP).

We will define economic growth in this study as a sustained increase in a country's real GDP and per capital real GDP. This is because GDP is the market value of all final goods and services produced within a country in a year, which includes all of private and public consumption, government outlays, investments and exports less imports that occur within a defined territory and is measured annually. Lipsey and Chrystal, (2007) stated that GDP is commonly used as an economic indicator of the overall health of an economy, as well as to measure the standards of living in a country. Adebayo, (1999) also stated that economic growth occurs if a rise in a nation's productive capacity, sustained over a long period, leads to a greater output of goods and services in the economy as a whole, to the extent that more goods and services are available for each person on the average. Economic growth is caused by two main factors; one of which is an increase in aggregate demand and the other is an increase in aggregate supply and could be generated by; an increase in the amount of physical capital goods in the economy, technological improvement, growing the labour force and increasing human capital. Reduction in tax rate increases the disposable income of businesses and encourages them to hire more labour and invest more in the business which will translate into more revenue to the government in the long run. Government gives tax incentives so as to increase its productive capacity in a certain period.

This is why Todaro and Smith, (2003) in their view stated that in the long-run, the government can only rely on the efficient and equitable collection of taxes as a more sustainable way to raise revenue to meet its development goals.

\subsection{Review of empirical literature}

Alan and Peter (2004) conducted a similar study on "the Failure of Economic Development Incentives". The study used multiple regression analysis to analyze the failure of economic development incentives. The study showed that incentives will lead to business investment and thus new jobs, producing an increase in the local demand for goods and services, giving rise to further rounds of economic growth, and that economic growth increases public revenues, thus allowing for improved public services or a decline in tax rates.

Klemm and Parys (2009) examined the Empirical Evidence on the Effects of Tax Incentives, considering two empirical questions about tax incentives: (1) are incentives used as tools of tax competition and (2) how effective are incentives in attracting investment? They prepared a new dataset of tax incentives in over 40 Latin American, Caribbean and African countries for the period 1985-2004. They used spatial econometrics techniques for panel data to answer the first question; they found an evidence for strategic interaction in tax holidays, in addition to the well-known competition over the corporate income tax rate and no evidence, however, for competition over investment allowances and tax credits. They used dynamic panel data econometrics to answer the second question and found evidence that lower corporate income tax rates and longer tax holidays are effective in attracting FDI, but not in boosting gross private fixed capital formation or growth. The finding that tax holidays are used as tool for tax competition and to affect FDI, while investment allowances do not seem to play a role in either case is interesting. There is also an interesting observation from their findings that the effect of tax rates and tax holidays on FDI, does not imply that there is an effect on total investment or economic growth.

Ogbonna and Appah (2012) examined the impact of tax reforms on Economic Growth in Nigeria: A Time Series Analysis. In their study, they used Time Series Data and employed co-integration tests to avoid spurious regression. The study also employed the Augmented Dickey - Fuller test for unit root. They also performed Granger Causality test between the dependent and independent variables. The e-view software was used for the analysis of data. They found that tax reforms is positively and significantly related to economic growth and that tax reforms cause economic growth. However, they recommended that sustainable economic growth cannot be attained with tax reform processes except obsolete tax laws and rates are reviewed in line with macroeconomic objectives, corrupt-free and efficient tax administrative machinery with well trained personnel and accountability and transparency of government officials in the management of tax revenue.

Worlu and Nkoro (2012) investigated Tax Revenue and Economic Development in Nigeria. In attempting to examine the impact of tax revenue on economic growth, they evaluated the time series features of the data by employing Augmented Dickey Fuller (ADF) and Philips-Perron(PP) to test for the unit root. They analyzed data 
collected using the three stage least square estimation technique. One major finding from their results is that tax revenue is indirectly related to foreign direct investment and real GDP through its impact on infrastructural development. The real GDP is significant though the sign is against apriori expectation as it presents with a negative rather than positive relationship with foreign direct investment. Also, foreign direct investment is with a contrary apriori sign and it is not significant. The interest rate, though with the wrong sign, is significant. Their recommendation was that for tax revenues to materialize its full potential on the economy, government will have to come up with fiscal laws and legislations and strengthen the existing ones in line with macroeconomic objectives, which will checkmate tax offenders in order to minimize corruption, evasion and tax avoidance and, improve the tax administrative machinery with personnel's and accountability and transparency of government officials in the management of tax revenue.

Adamu S. (2014) examined the impact of tax incentives on economic growth and industrial development of companies in Nigeria. He adopted survey and content analytical method in his study and generated from both primary and secondary sources. The technique used for data analyses was chi-square test and statistical package for social sciences (SPSS.) He found that there are significant relationships between tax incentive and economic growth which was indicated by responses of the respondents and test of hypothesis using the SPSS. He recommended that the government should formulate fiscal policies that would increase tax incentives granted to companies especially to small and medium scale businesses, in order to enhance the micro and macro-economic growth and development.

Siyanbola et al (2017) examined Tax incentives and industrial/economic growth of sub-Saharan African States using data obtained from World Bank Data Index (WDI), Federal Inland Revenue Services (FIRS), Ghana Revenue Authority (GRA), Nigerian Investment Promotion Commission (NIPC), Ghana Investment Promotion Centre (GIPC) and Action-aid International (AAI) for 4-year period between 2011 and 2014. A linear regression model was estimated using the Ordinary Least Square technique. They found that there is a 0.529:1 relationship between tax incentives and GDP, which shows that Africa is not doing much at the moment to encourage productivity. The result also indicated positive effect of tax incentives on industrial and economic growth, suggesting that increasing tax incentives to productive and priority sectors of African economy will increase the continent's gross domestic products. It was therefore recommended that Sub-Sahara African States should grant more incentives to those sectors and monitor closely the administration of such incentives.

Ivana D. and Darko M. (2017), examined tax incentives as a factor of economic growth using data based on opinion, values, expectations and perceptions of foreign investors on the importance of tax incentives in certain areas of their business in Serbia. The methodology was based on a quantitative approach to primary data collection through surveys of relevant participants, comparison of the collected data and the analysis of causality of the researched phenomena. According to their results, foreign investors doing business in Serbia consider the most significant tax incentives; those relating to the tax on income of legal entities, tax incentives for the employment of new employees and tax incentives for export companies, while the importance of other incentives is far lesser. They recommended that because there are good prospects for increasing the inflow of foreign capital, it is necessary to offer investors a wider range of tax incentives as soon as possible, taking into account other variables that may have an impact on investors when choosing Serbia as an investment destination, which would lead to the improvement of the business environment and economic growth.

Nnubia, I. C. and Obiora F. C. (2018), examined the effect of tax incentives on economic growth in Nigeria. They adopted the ex post facto research design, using data sourced from the CBN Statistical Bulletin. They also used the Ordinary Least Square Method in their data analysis. Their results show that annual allowance was positive and has significant impact on economic growth in Nigeria while investment allowance was negative and has significant impact on economic growth in Nigeria. They recommended that the policy makers and the government should formulate and enact laws that increase the rate of investment allowance from $15 \%$ to $20 \%$ on plant and machineries used in manufacturing business.

The impact of corporate taxes on economic growth has also been investigated extensively by some scholars. For example, Lee and Gordon (2005) used cross-country data ranging from 1970 to 1997 to investigate the impact of tax policies on a country's economic growth. Their study finds that increases in corporate taxes have a negative impact on economic growth. In fact, a ten percent reduction in the corporate tax rate will result in a one to two percent increase in the annual rate of growth. Similar conclusions about the impact of corporate taxes on economic growth are reached by Djankov, Ganser, McLiesh, Ramalto, and Shleifer (2008). Their cross-sectional study of 85 countries in 2004 indicates that corporate taxes have a large negative impact on aggregate investment and economic growth in countries under their empirical investigation.

Clearly, the findings in this literatures, suggest that incentives may also be important. Surprisingly, however, not many studies have documented the long-term effects of these tax policies on economic growth, even though some found a significant effect, but uncertainty about its size remains. This paper has become part of the series of studies analyzing the effect of tax incentives on the investment growth in Nigeria so as to provide clue on contending issues and fill some research gap. 


\subsection{Theoretical framework}

This study is anchored on two theories: Supply-Side Theory and Economic Growth theory.

2.4.1 Supply-Side Theory: The term "supply-side economics or supply-side fiscalists" according to Atkinson (2006) was first used by Herbert Stein, a former economic adviser to President Nixon, in 1976. Supply-side theorists advocate income tax reduction because it increases private investment in corporations, facilities, and equipment. The supporters of this theory felt that in an economy where the corporate tax rate is very high, that reducing the tax rates to the appropriate level can increase the after tax profits of firms and thereby causing faster economic growth and development in the economy. Supply-side theorists belong to the school of macroeconomic thought that believes that by lowering the barriers for people to produce or supply goods and services in an economy, such as reducing income tax rates and capital gains tax rates, and by making provisions for greater flexibility in the system; only then that economic growth and development can be created most effectively. The idea is to stimulate production for a sustainable economic growth and development in a country; this is because as the level of output increases, it will increase government tax revenue thereby making funds available for spending to increase without increasing tax rates. Supply-siders belief that at the reduction of tax rates to attract investors, that the willingness of the producers to produce more goods and services will boost economic growth and stability in an economy. The advocates of low tax rates argued based on this theory to be able to explain the relationship that exist between income tax rates and economic growth.

2.4.2 Economic Growth Theory: Naturally, human desires and unlimited wants encourage continuous increase in productivity thereby stimulating economic growth. The more firms continue to work for more profit then the real gross domestic product per person will continue to increase. Because of the quest for higher profits, companies look for a better way of wining competitive advantage over their competitors. This is usually done when profits become low as a result of severe competition from other companies in the same line of business. Economists who advocate classical growth theory believed population explosion is caused by a temporary increase in real gross domestic product per person, but when this explosion will in turn decrease real gross domestic product. Gross domestic product increases because of the increase in the production of goods and services (i.e. output) which is caused by a reduction in the corporate income tax rate and award of other incentives. The supporters of this theory came up with the idea of a subsistence level to interpret the theory. The idea was that when the real gross domestic product increases more than this level, then people would feel that they have got more than enough, therefore, population will increase causing the real gross domestic product to come down to the subsistence level.

\section{Methodology}

In most of the developing countries in Africa, economic growth is influenced to a reasonable extent by external factors which may include exchange rate of the domestic currency against other currencies, trade openness, inflation, foreign direct investment and so many others. We measured economic growth as the ratio of gross domestic product. This ratio is expected to be high and positively associated with global indicators. In Nigeria which is the study environment, the gross domestic product is not reflecting the expectations of the global world. Yearly data were generated from Central Bank of Nigeria statistical bulletin and the Federal Inland Revenue Service between 1981 which was the period the oil prices collapsed in the international market to 2016 .

The econometric method was the most appropriate since we will be interested in model specification, measuring of the parameters of economic relationship.

The model equation is stated in Error Correction Form to establish whether there will be long run relationship between economic growth and tax incentives assuming linear relationship.

Ln GDP $=\beta_{0}+\beta_{1}$ LnACIT $_{t}+\beta_{2}$ LnINVA $_{t}+\beta_{3}$ LnINTR $_{t}+\beta_{4}$ LnPOPL $_{t}+\beta_{5}$ LnTOPN $_{t}+$ et. $\quad \ldots 1$

Where; $\mathrm{Ln}=$ Elasticity; $\beta_{0}=$ Constant and

$\beta_{\mathrm{i}}(\mathrm{i}=1,2, \ldots . \mathrm{n})=$ the parameters to be estimated

EGR $=$ Economic Growth, proxied by Gross Domestic Product,

Tax Incentives are represented by Company Income Tax and investment Allowance while the other variables are to moderate.

$$
\begin{aligned}
& \text { ACIT = Company income tax allowance, } \\
& \text { INVA = Investment allowance } \\
& \text { INT = Interest Rate, } \\
& \text { POP = Population, } \\
& \text { TOP = Trade Openness, }
\end{aligned}
$$

Company income tax allowance and investment allowance are chosen as proxy for tax incentives because they are general incentive for all companies. Their impact will be more in the economy because every company/firm in Nigeria will be affected and will benefit positively or negatively while all other tax incentives will only benefit foreign companies of which domestic companies will not benefit.

To transform our model for long-run analysis, an Error Correction Model (ECM) is specified thus: $\Delta \mathrm{GDP}_{\mathrm{t}}=\beta_{0}+\beta_{\mathrm{i}} \sum \Delta \mathrm{x}_{\mathrm{i}}+\lambda \mathrm{ECM}_{\mathrm{t}-1}$ 
Where,

$\Delta \mathrm{GDP}_{\mathrm{t}}=$ differenced or stationarity level of gross domestic product

$\Delta \mathrm{x}_{\mathrm{i}}=$ differenced exogenous variables in the model

$\beta_{0}=$ intercept

$\beta_{\mathrm{i}}=\beta_{1}, \beta_{2}, \beta_{3}, \beta_{4}$ (slopes of the model)

$\lambda=$ ECM parameter measuring the adjustment to previous equilibra achieved in the current period.

Other variables remain as defined before.

\section{Results}

Dependent Variable: Output Growth: Proxied by Gross Domestic Product (GDP)

Pre-estimation Test

Table 1: The result of the stationarity test:

\begin{tabular}{|l|l|l|l|l|}
\hline Variables & ADF & $1 \%$ & $5 \%$ & Order of Integration \\
\hline LGDP & -13.28 & -3.50 & -2.89 & 1 st order \\
\hline ACIT & -11.32 & -3.50 & -2.89 & 1 st order \\
\hline INVA & -11.21 & -3.50 & -2.89 & 1 st order \\
\hline INTR & -11.16 & -3.50 & -2.89 & 1 st order \\
\hline POPL & -15.09 & -3.50 & -2.89 & 1 st order \\
\hline TOPN & -11.17 & -3.50 & -2.89 & 1 st order \\
\hline
\end{tabular}

\section{Source: Author's computation}

The pre-estimation test of stationarity has become a rule in every time-series study because of the need to make policy based on analysis from reliable data. The first pre-estimation test in any time series analysis is the test of stationarity. Dick-Fuller test for Stationarity was presented in table 1 above, all the variables are stationary at $1^{\text {st }}$ difference which shows that the mean and variance of the variables are constant over time.

Table 2: Regression Result; Dependent Variable: Gross Domestic Product (LGDP)

\begin{tabular}{|l|l|l|l|l|}
\hline \hline Variables & Co-efficient & Std. error & ${ }^{\prime}{ }^{\prime}{ }_{c}$ & P-value \\
\hline CONST & .0085375 & .0090365 & 0.94 & 0.347 \\
\hline ACIT $_{-1}$ & -0016148 & .0146933 & -0.11 & 0.913 \\
\hline INVA-1 $_{-1}$ & .0030991 & .0013871 & 2.23 & 0.027 \\
\hline INTR $_{-1}$ & .0039642 & .0028353 & 1.40 & 0.165 \\
\hline POPL-1 $^{\text {TOPN }}-1$ & .0525299 & .0055448 & 9.47 & 0.000 \\
\hline RESID & .8666662 & .1553412 & 5.58 & 0.000 \\
\hline
\end{tabular}

\section{Source: Author's computation}

$\mathrm{R}^{2}=0.5926 ; \quad \mathrm{R}_{\mathrm{a}}^{2}=0.5720 ; \quad \mathrm{F}(6,119) 28.85 ;$ F-Prob. $=0.0000$

DW $\quad(6,127)=2.015$

Dependent Variable: Output Growth: proxied by Gross Domestic Product (GDP)

The value of the coefficient of determination $\left(\mathrm{R}^{2}\right)$ is 0.5926 which shows that the changes in the values of the independent variables account for 59 percent of the changes in economic growth within the period of study.

Table 3: Specification test

\begin{tabular}{|l|l|l|l|l|}
\hline F-Statistics & 28.85 & Calculated & $1 \%$ & $5 \%$ \\
\hline F-Prob & & & 3.82 & 3.10 \\
\hline
\end{tabular}

\section{Source: Analysis of Data}

The F-Test tests for the statistical significance of the entire regression model. The value of the calculated and critical ' $F$ ' in table 3, suggests that the model is well specified.

From the value of Durbin-Watson statistics also has a value of 2.015 in the result which shows that the model is not suffering from autocorrelation and by that, the error terms are not correlated from year to year.

Table 4: Co-integration/Unit Root Test:

\begin{tabular}{|l|l|l|l|}
\hline Variable & ADF & $1 \%$ & $5 \%$ \\
\hline Residual & -13.95 & -3.50 & -2.88 \\
\hline
\end{tabular}

\section{Source: Author's computation}

From the table above, the value of the residual $(\mathrm{ADF}=-13.95)$ is higher than the $5 \%$ critical value. It means that the dependent and independent variables are cointegrated, that means that there is a long-run relationship between them. Therefore, the trend between the dependent and independent variables continued in the long-run. Thus, there is need for error correction (ECM).

The result of the error correction model shows that the residual appeared with the correct sign with a coefficient of -0.0360893 , which shows the speed of adjustment from disequilibrium to equilibrium. This speed of 
adjustment is high because in a year, the dependent and independent variables adjust by -0.0361 in approximation.

When there is a 100 percent fall in company income tax, then economic growth will only adjust by $-3.61 \%$ percent. The speed is low to make any significant impact in economic growth.

\subsection{Discussion}

The economic theory argument relates to signs of the coefficient of the variables. The major policy variable in the study is tax incentive represented by corporate income tax allowance and investment allowance. Tax is a cost in the production of goods and services; and an increase in tax means that the cost of production will increase. Therefore, economic theory posits negative relationship between tax and output growth. The regression result shows that company income tax allowance and investment allowance satisfied the a priori expectation. When a variable satisfies the a priori expectation, it can now be judged as being effective in causing a change in the dependent variable.

The independent variable of interest which is tax incentive (company income tax and investment allowance) are correctly signed indicating the relationship between tax incentive and output growth. This is consistent with the submission of Lee and Gordon (2005) and Djankov, Ganser, McLiesh, Ramalto, and Shleifer (2008) which showed that increases in corporate taxes has a negative impact on economic growth. Ogbonna and Appah (2012) also in their study showed that tax reform is positively and significantly related to economic growth. Ferede and Dahlby (2012), also affirmed in their study that a higher corporate income tax rate is associated with slower economic growth.

The result of the effect of tax incentives on output growth as presented above has some course of concern for policy makers in Nigeria. By tax incentive, government continues to review tax policy in the country in such a way that they will stimulate the production and consumption of goods and services. Company income tax and investment allowance are among those tax policies often reviewed to stimulate the production of goods. From time to time, company income tax is reviewed downwards to make available more tax allowance for companies, so as to enable profit after tax of companies to increase. Investment allowance is as well from time to time reviewed upwards to entice investors. This is because an increase in profit enables a company to have enough funds for reinvestment and increase in investment translates to an increase in production of goods and services. Looking at the result, one can see that the policy is not doing badly in terms of expected result. However, one will understand that tax is a part of those cost of production. Other factors contribute to the growth of production of goods and services. For example, electricity supply is one of the major cost components in the production of goods and service. For more than a decade now, the supply of electricity in Nigeria has been very poor. Many companies that cannot afford private power supply have closed down. Some other companies like Michelin have relocated to a neighbouring West Africa, Ghana. All this behaviour undermines the ability of the real sectors of the economy to generate economic growth as expected.

Moreover, consumers' behaviour in Nigeria is another factor that can be considered when one is thinking about how effective a policy will be in stimulating economic growth in Nigeria. Nigerian consumers are amenable to demonstration effect. Even when the locally made goods is better in quality, an average Nigerian consumer will like to go for a foreign made good of a lower quality instead of the one produced in the country, all in an effort to join the Jones. Such behavior depresses domestic production of goods and services.

In order to make company income tax allowance and investment allowance effective in stimulating economic growth in Nigeria, it is good that policy makers equally look at other factors that affect economic growth. The factor is the consumption of foreign made goods and services. Government can combine lower company income tax and higher investment allowance with higher import tax. Such policies will complement each other and the result will be as expected. There is equally the need to look at the business environment such as security and power supply. These factors seriously affect the incentive to produce.

\section{Conclusion}

The study so far shows that tax incentives have significantly impacted on economic growth within the period of study. However, the impact on economic growth is our major concern. This work has analyzed specific aspects of Nigerian tax incentive policy as indicated in the Draft Nigerian Tax Policy with the very important policy initiatives of the government. However, tax policy is a major determinant of other macroeconomic indices for both developed and developing economies. There is a relationship between tax structure and economic growth of any economy, and the study based on its evaluation will assist policy makers put up some reasonable policies as means of putting the economy back into a sustainable growth path. Based on the reviewed literature, from lessons derived from international examples, there is hope that tax incentive policies in Nigeria, if prudently and selectively applied in conjunction with other economic policies, may well contribute to sustainable economic growth and development.

\section{REFERECNES}

Adamu S. (2014), The Impact of Tax Incentives on Economic Growth and Industrial Development in Nigeria; 
International Journal of Advanced Studies in Economics and Public Sector Management Volume 2, No. 1 January, 2014, ISSN (Electronic):1741-8771 ISSN (Print): 1741-8763

Adebayo, A. Economics: A Simplified Approach. Vol. 2 (2nd ed.). Lagos. African International Publishing, (1999)

Alan, P. \& Peter, F. (2004), The Failures of Economic Development Incentives, Journal of the American Planning Association, Winter 2004, 70,(1) 2-3

Asiodu, D.S. (2003), Industrial Policy and Incentives in Nigeria; Nigeria Journal of Economic and Social Studies. 2: $161-167$.

Djankov, S. et al, (2008), The Effect of Corporate Taxes on Investment and Enterpreneurship."Working Paper, American Law \& Economic Association Annual Meeting, 2008.

Dwivedi D.N. (2004), Managerial Economics. 6th Edition, Vikas Publishing House PVT Ltd., New Delhi. 596P

Fletcher K. (2002), Tax Incentives in Cambodia, Lao PDR, and Vietnam. Prepared for the IMF Conference on Foreign Direct Investment: Opportunities and Challenges for Cambodia, Lao PDR and Vietnam Hanoi, Vietnam, August 4, 16-17.

Holland D. \& R.J. Vann (1998): "Income tax incentives for Investment” Tax design and drafting, 2, 985-987

Hoyt W. H., Jepsen C. \& Troske K. R. (2008) Business Incentives and Employment: What Incentives Work and Where? Institute for Federalism and Intergovernmental Relations (IFIR) Working Paper No. 2009-0

Ivana D. and Darko M. (2017), Tax incentives as a factor of economic growth; In: The state and the market in economic development: in pursuit of millennium development goals. The International Institute for Development Studies, Brisbane, Australia, pp. 93-107. ISBN 978-0-646-94775-4

Klemm, A., (2009), "Causes, Benefits and Risks of Tax Incentives," IMF Working Paper 09/21 (Washington: International Monetary Fund).

Klemm A. \& Parys, S. (2009). Empirical Evidence on the Effects of Tax Incentives. IMF Working Papers; 9136(200). 1-25.

Kuewuni, M. (1996): “A Critique of tax incentives in Nigeria” Tax News, 2 (1) 4-8

Lee, Y. and Gordon, R. H. (2005); Tax Structure and Economic Growth. Journal of Public Economics, Vol. 89, Issues 5-6, 1027-43.

Lipsey, R. \& Chrystal, A. (2007).Economics. Eleventh Edition, Oxford Publishers

Morisset J. and N. Pirnia (2003); How Tax Policy and Incentives Affect Foreign Direct Investment: A Review' in Wells et al, Using Tax Incentives to Compete for Foreign Investment: Are They Worth the Costs? 85-87.

Nnubia, I. C. \& Obiora F. C. (2018), Effect of Tax Incentives on Economic Growth in Nigeria; International Journal of Social Sciences and Conflict Management, Volume 3, Number 2, June 2018, ISSN : 25367234 (Print): 25367242

Ogbonna G.N. \& Appah E.(2012), Impact of Tax Reforms and Economic Growth of Nigeria: A Time Series Analysis. Current Research Journal of Social Sciences 4(1): 62-68

Ohiorhenuan, J. F. E. (1987), Re-colonising Nigerian Industry: the First Year of the Structural Adjustment Programme'; Structural Adjustment Programme in a Developing Economy: the Case of Nigeria, (Nigerian Institute of Social and Economic Research, Ibadan) 133-143.

Onimode, B. (1989) IMF and World Bank Programmes in Africa; in Bade Onimode (ed) Vol. 1: the Economic Impact, The IMF, the World Bank and the African Debt, (Zed Books, London: 1989), 32-34;

Prillaman S. A. and Meier K. J. (2014), Taxes, Incentives, and Economic Growth: Assessing the Impact of Probusiness Taxes on U.S. State Economies; The University of Chicago Press Journals, Vol. 76 No. 2, April 2014

Siyanbola T. T., Adedeji S. B., Adegbie F. F. \& Rahman M. M. (2017), Tax incentives and industrial/economic growth of sub-Saharan African States; Journal of Advanced Research in Business and Management Studies Vol. 7, Issue 2 (2017) 78-90

Todaro, P. M. \& Smith, C. S. (2003). Economic development; Eighth Edition, Addison Wesley

Worlu C. N. and Nkoro E. (2012) Tax Revenue and Economic Development in Nigeria: A Macro econometric Approach Academic Journal of Interdisciplinary Studies Published by MCSER-CEMAS-Sapienza University of Rome; Vol 1 No 2 November 2012 ; ISSN 2281-3993

National Economic Empowerment and Development Strategy (NEEDS) Report, (2004) (Nigerian National Planning Commission, Abuja: 2004) Chapter 6; Sectoral Strategies, 68 